Published in final edited form as:

Prog Neuropsychopharmacol Biol Psychiatry. 2009 November 13; 33(8): 1329-1335. doi:10.1016/j.pnpbp. 2009.05.022.

\title{
Modulation of Glutamatergic Synaptic Transmission in the Bed Nucleus of the Stria Terminalis
}

\author{
Zoé Anastasia McElligott ${ }^{1}$ and Danny G. Winder ${ }^{1,2,3}$ \\ 1 Vanderbilt Brain Institute, Vanderbilt University Medical Center, Nashville, TN, USA \\ 2 Department of Molecular Physiology and Biophysics, Vanderbilt University Medical Center, \\ Nashville, TN, USA \\ ${ }^{3}$ Kennedy Center For Human Development, Vanderbilt University Medical Center, Nashville, TN, \\ USA
}

\begin{abstract}
Glutamate, catecholamine and neuropeptide signaling within the bed nucleus of the stria terminalis (BNST) have all been identified as key participants in anxiety-like behaviors and behaviors related to withdrawal from exposure to substances of abuse. The BNST is thought to serve as a key relay between limbic cognitive centers and reward, stress and anxiety nuclei. Human studies and animal models have demonstrated that stressors and drugs of abuse can result in long term behavioral modifications that can culminate in psychological diseases such as addiction and post-traumatic stress disorder. The ability of catecholamines and neuropeptides to influence synaptic glutamatergic transmission (stemming from cognitive centers) within the BNST may have profound consequences over these behaviors. In this review we highlight studies examining synaptic plasticity and modulation of excitatory transmission within the BNST, emphasizing how such modulation may result in alterations in anxiety and reward related behavior.
\end{abstract}

\section{Introduction}

The ability to integrate and interpret stressful and rewarding situations is necessary for an organism's survival. Evidence suggests that maladaptive processes in brain regions associated with stress and reward may lead to pathological anxiety conditions (generalized anxiety disorder, post-traumatic stress disorder, panic disorder) and addiction. The bed nucleus of the stria terminalis (BNST) - a component of the "extended amygdala" - has been shown to play a role in contextual conditioned and unconditioned fear responses; anxiety-like behaviors; affective behaviors related to drug/alcohol dependence; and, stress-induced reinstatement of drug seeking, a model of stress-induced relapse (Walker and Davis, 1997; Shaham et al., 2000; Sullivan et al., 2004; Fendt et al., 2005; Olson et al., 2006). This is particularly interesting given the ample evidence for the co-morbidity of substance abuse and anxiety disorders (George et al., 1990; Kushner et al., 2000; Breese et al., 2005; Sareen et al., 2006; Vik, 2007; Herrero et al., 2008). Additionally, as many of these behaviors are postulated to involve cortical and limbic regions that provide glutamatergic inputs to the BNST, alterations in the strength

Corresponding Author: Danny G. Winder, Ph.D., Department of Molecular Physiology \& Biophysics, Room 724B, RRB 1, Vanderbilt University School of Medicine, Nashville, TN 37232-0615, Phone: (615) 322-1144, Fax: (615) 343-0490, danny.winder@ vanderbilt.edu.

Publisher's Disclaimer: This is a PDF file of an unedited manuscript that has been accepted for publication. As a service to our customers we are providing this early version of the manuscript. The manuscript will undergo copyediting, typesetting, and review of the resulting proof before it is published in its final citable form. Please note that during the production process errors may be discovered which could affect the content, and all legal disclaimers that apply to the journal pertain. 
of these connections within the BNST are hypothesized to play roles in the pathogenesis of addiction and anxiety disorders. In this review we will explore the current understanding of synaptic physiology in the BNST and begin to form a conceptual framework for beginning to interpret potential behavioral correlates.

\section{BNST: early insights and anatomical positioning}

Behavioral studies have highlighted the BNST as a region at the crossroads of reward and stress/anxiety networks. The hypothalamic-pituitary-adrenal (HPA) axis functions to engage the body's stress response. The paraventricular nucleus of the hypothalamus (PVN) releases corticotrophin releasing hormone (CRH) in the pituitary gland, which in turn releases adrenocorticotrophic hormone (ACTH) into the bloodstream where it acts on the adrenal gland to release corticosterone. Although limbic and cortical projections had been shown to regulate HPA axis function, their efferents often terminate prior to the PVN, with strong evidence for the BNST to serve as a key relay between these regions (Cullinan et al., 1993). Early work demonstrated that a portion of the BNST projections to the PVN express GABAergic markers (Cullinan et al., 1993). Additionally, electrical stimulation of the lateral BNST decreases plasma levels of corticosterone following electrical stimulation of the lateral BNST (Dunn, 1987) and glutamate microstimulation in the BNST induces inhibitory postsynaptic potentials in the magno- and parvocellular cells of the PVN (Boudaba et al., 1996)., Swim stress, moreover, increases Fos immunoreactivity in glutamate decarboxylase (GAD, the enzyme that produces GABA) containing BNST-PVN projecting neurons (Cullinan et al., 1996). These data have led researchers to infer that the BNST is a member of a collective group of nuclei that provide a strongly integrated braking mechanism controlling HPA axis induction (Cullinan et al., 2008). In contrast perhaps to these data, BNST lesions reduce interleukin- $1 \beta$ induced Fos activation in the PVN and attenuate ACTH levels (Crane et al., 2003), demonstrating its critical role as a relay for stress axis activation. This may be reconciled by more recent lesion studies that have demonstrated that BNST subregions can potently regulate HPA axis function in divergent ways (Choi et al., 2007). Furthermore, these subregions appear to regulate HPA axis function differently depending on the organisms exposure to an acute stressor following chronic stressors vs. an acute stressor alone suggesting that plastic changes within BNST microcircuitry may have profound influence over HPA axis function (Choi et al., 2008a; Choi et al., 2008b).

In addition to regulation of HPA axis, the BNST also appears to mediate other affective behaviors. Infusion of an AMPA receptor antagonist into the BNST and excitotoxic lesions diminish anxiety-like behavior as measured by light enhanced startle and CRF enhanced startle respectively (Lee and Davis, 1997; Walker and Davis, 1997). Furthermore lesioning the BNST enhanced learned despair during a forced swim task (Schulz and Canbeyli, 2000), impairs fear conditioning with a prolonged stimuli, and reinstatement of conditioned fear (Waddell et al., 2006). Single administration of ethanol (via various routes of administration) also activates Fos in dlBNST neurons (Knapp et al., 2001; Crankshaw et al., 2003) (but see (Herring et al., 2004)). Finally, blocking opiate receptors specifically within the BNST attenuates heroin selfadministration (Walker et al., 2000). While these studies raise the question as to how the BNST mediates these behaviors, some of which may seem divergent, together they suggest that as a whole, the BNST may serve as a relay between these limbic, cortical regions, and reward centers and the HPA axis, and may play a key role in behavioral responses to stress, anxiety and substances of abuse.

Closer inspection of the anatomy reveals that the BNST receives glutamatergic inputs from several brain regions that play roles in the manifestation of various types of behavior, notably cognitive and emotional processes; and, furthermore outputs to several regions, notably regions involved with reward, feeding behavior and stress (Dong et al., 2001b; Dong and Swanson, 
2004). Of note, the BNST receives inputs from the central (a GABAergic projection), medial and basolateral nuclei of the amygdala, the hippocampus and the prefrontal, insular and limbic cortices (Cullinan et al., 1993; McDonald, 1998; Dong et al., 2001a). These regions have also been identified as plausible contributors to behavioral responses from processive stressors (psychological stressors like restraint stress as opposed to systemic stressors like sepsis) and drugs of abuse.

Ascending modulatory transmitter systems also project heavily to the BNST. The BNST receives one of the most robust noradrenergic innervations in the CNS (Forray and Gysling, 2004). These projections arise mainly from the nucleus of the tractus solitarius (NTS) and the A1 cell groups via the ventral noradrenergic bundle (VNAB), although some of the projections also arise from the dorsal noradrenergic bundle (DNAB) stemming from the locus coeruleus (Ricardo and Koh, 1978; Woulfe et al., 1988; Banihashemi and Rinaman, 2006). The majority of these projections are made in the ventrolateral BNST (vlBNST), however, the dorsolateral BNST (dlBNST) receives innervation as well (Egli et al., 2005; Bienkowski and Rinaman, 2008). The dlBNST also receives dopaminergic innervation arising from both the ventral tegmental area (VTA) as well as the periaqueductal grey (PAG) (Hasue and ShammahLagnado, 2002; Meloni et al., 2006). In addition to classic neuromodulators, the BNST also receives input from neuropeptide containing neurons, for example CRF (Sakanaka et al., 1986) and neuropeptide Y (NPY) (Walter et al., 1991; Larriva-Sahd, 2006).

\section{Properties of BNST neurons}

As with the neighboring central nucleus of the amygdala and shell of the accumbens, the majority of the neurons within the BNST are GABAergic, however, there does appeart to be a distinct glutamatergic population of projection neurons as well as evidenced by functional assays and the presence of mRNA of multiple vesicular glutamate transporter genes (Georges and Aston-Jones, 2002; Allen Institute for Brain Science, 2008). In addition, they express a variety of neuropeptides including CRF, enkephalin, NPY and substance P (Malsbury and McKay, 1987; Arluison et al., 1990; Walter et al., 1991; Champagne et al., 1998). While the majority of neurons appear somewhat similar in morphology to medium spiny neurons, Golgiimpregnation studies reveal an impressive array of cellular morphologies (McDonald, 1983; Larriva-Sahd, 2006). This diversity combined with strong evidence for a number of subnuclei within the BNST suggests a complex neurocircuitry.

To begin to attempt to understand the neurophysiology of this circuitry, we and others have begun characterizing the electrical properties of neurons within the BNST. The neurons in the BNST appear very heterogeneous between the dorsal and ventral subdivisions and even within the subdivisions. Various BNST neurons have been shown to have low threshold spiking (likely mediated via T-type calcium current), $\mathrm{I}_{\mathrm{h}}, \mathrm{I}_{\mathrm{A}}$ and inward rectifying potassium currents, and a persistent sodium current (Rainnie, 1999; Egli and Winder, 2003; Hammack et al., 2007). This suggests that synaptic input to these cells may be differentially integrated, which may have an important effect on subsequent behavior. Recently it has been shown using retrograde tracers that neurons projecting from the BNST to the VTA have distinct physiological properties. Neurons projecting to the VTA have lower capacitance, higher input resistance, inward rectifying potassium currents and lack $\mathrm{I}_{\mathrm{h}}$ currents (Dumont and Williams, 2004; Kash et al., 2008a). These properties could suggest that these cells are more easily excited by synaptic input and the low threshold spike activity in the ventral BNST may result in increased bursting phenomena (Egli and Winder, 2003). Additionally, dorsal BNST neurons, as opposed to these VTA projection neurons which mainly reside in the ventral BNST, appear to be under tonic inhibition in the ex vivo slice preparation (Egli and Winder, 2003). Furthermore, anatomical data suggests that portions of the dorsal BNST project to subnuclei within the ventral BNST (Dong et al., 2000). Tonic inhibition of presumably inhibitory dorsal BNST neurons, therefore, 
could potentially disinhibit ventral BNST neurons which may have profound impact on the functional output of the nucleus as a whole. Examining the physiological properties of BNST neurons targeting other nuclei, the paraventricular nucleus of the hypothalamus (PVN) for example, and intrinsic BNST projections will no doubt prove useful to future studies examining synaptic integration and modulation.

\section{Homosynaptic modulation}

The modification and remodeling of glutamatergic synapses have long been postulated to play a role in classical learning and memory. Studies have correlated plasticity at glutamate synapses to learning paradigms by demonstrating that interfering with or potentiating the induction/ expression of the plasticity in various brain regions can disrupt or enhance several learned behaviors (Malenka and Bear, 2004), as well as demonstrating that plasticity at these synapses is induced by behavioral stimulation that promotes learning (Whitlock et al., 2006).

More recently these concepts have been explored in the context of reward and substance abuse. Interfering with glutamatergic transmission alters behavioral paradigms of addiction (Wolf, 1998). Several drugs of abuse with differing pharmacological targets and stress have been shown to increase AMPA/NMDA ratios (suggesting an induction of long term potentiation LTP) in the ventral tegmental area (VTA) (Ungless et al., 2001; Saal et al., 2003). Moreover, mice lacking the GluR1 subunit of the AMPA receptor (AMPAR) do not exhibit increases in AMPA/NMDA ratios to cocaine or stress challenges in the dopaminergic neurons of the VTA (Dong et al., 2004). These findings have led to the theory that addiction is a pathological hijacking of learning-like cellular correlates in reward centers (Kauer and Malenka, 2007).

\section{Long Term Potentiation}

To begin to assess the ability of neurons within the BNST to undergo synaptic remodeling our group first described an extracellularly recorded synaptic response to local stimulation and demonstrated that two $100 \mathrm{~Hz}$ trains of stimuli (1 second each) can produce an NMDA receptor (NMDAR) dependent long term potentiation (LTP) in this region (Weitlauf et al., 2004; Weitlauf et al., 2005). Interestingly, the early portion of this LTP was found to be attenuated by acute, in vitro application of ethanol in a manner that was dependent on $\mathrm{GABA}_{\mathrm{A}}$ signaling and mimicked by incomplete NMDAR blockade. Furthermore it was noted that ethanol reversibly attenuates NMDAR currents by directly acting on receptors that containe the NR2B subunit (Weitlauf et al., 2004; Kash et al., 2008a). Previously, it had been proposed in the hippocampus and cortex that the NR2A subunit was responsible for the induction of NMDAR dependent LTP (Liu et al., 2004; Massey et al., 2004; Mallon et al., 2005), however, our group demonstrated that LTP in the dlBNST was intact in mice lacking NR2A subunits and that the pharmacological blocker used to previously confirm NR2A dependence in mediating LTP was not selective in brain slices at the concentration previously used by other researchers (Weitlauf et al., 2005).

\section{Long Term Depression}

In addition to ionotropic receptors, glutamate also exerts its actions through G-protein coupled receptors (GPCRs) known as metabotropic glutamate receptors (mGluRs). Although mGluRs are not direct pharmacological targets of drugs of abuse, mGluR5 knockout mice do not selfadminister cocaine nor do they exhibit locomotor responses to psychostimulants (Chiamulera et al., 2001). Moreover the mGluR5 antagonist MPEP has been shown to reduce the locomotor properties of cocaine and reduce conditioned place preference to cocaine, morphine and amphetamine (McGeehan and Olive, 2003; Herzig and Schmidt, 2004; Herzig et al., 2005). The BNST has been shown to express all three families of mGluRs and stimulation of all three mGluR families reduces glutamatergic transmission in the dIBNST (Grueter and Winder, 
2005; Grueter et al., 2006). Activation of group I (specifically mGluR5) and group II mGluRs can induce long term depression (LTD) of glutamatergic synapses in the dlBNST, albeit via different mechanisms. Typically coupled to $\mathrm{G}_{\mathrm{i} / \mathrm{o}}$, group II mGluRs depress synaptic transmission via a presynaptic mechanism (Grueter and Winder, 2005). mGluR5 activation, which typically couples to $G_{q}$, however, induces LTD via extracellular regulated kinase 1 (ERK1) signaling (Grueter et al., 2007; Grueter et al., 2008)). Further experiments using postsynaptic delivery of GTP- $\gamma-\mathrm{S}$ and a dynamin inhibitory peptide suggests that the mGluR5 receptor is on the postsynaptic cell and that the LTD is maintained by postsynaptic modifications; and, requires clathrin-dependent endocytosis and actin remodeling thus suggesting a loss of AMPAR at the synaptic cleft by receptor internalization (Grueter et al., 2008). Furthermore, expression of this LTD following mGluR5 stimulation, but not the initial decrease in glutamatergic efficacy observed in the time course, is prevented by in vivo administration of cocaine. This occlusion can be rescued by prior administration of the mGluR5 antagonist, MPEP in vivo (Grueter et al., 2008). This suggests that cocaine signals through mGluR5 in vivo to exert effects over this plasticity in the dlBNST.

Cocaine administration can also regulate other forms of plasticity within the BNST. Dumont and colleagues found that self-administration of cocaine or palatable food, but not yoked administration, increased AMPA/NMDA current ratios (an indirect measure of LTP) in VTAprojecting neurons in the vlBNST (Dumont et al., 2005; Dumont et al., 2008), thus suggesting a requirement for active drug seeking. Additionally it has recently been shown that chronic morphine administration can also increase AMPA/NMDA ratios in neurons projecting from the BNST to the VTA (Dumont et al., 2008). Interestingly, this was shown to be specific to the location of the stimulating electrode, suggesting that this morphine-induced plasticity may be input specific.

In addition to LTD, activation of group I mGluRs in the BNST can also induce the release of endocannabinoids from the postsynaptic cell to act on presynaptic cannabinoid type 1 receptors (CB1Rs) (Grueter et al., 2006). Activation of these receptors decreases release probability, thus reducing glutamatergic efficacy. Recently Georges and colleagues showed that glutamatergic projections from the infralimbic cortex can stimulate BNST neurons (both dorsally and ventrally) to excite approximately $80 \%$ of the dopamine neurons in the VTA (Massi et al., 2008). The majority of this excitability was then demonstrated to be blunted by the addition of CB1R antagonists infused into the BNST which may demonstrate a mechanism for cannabinoid signaling to decrease the positive valance behaviors (such as pleasurable feelings) mediated by VTA activation.

\section{Heterosynaptic modulation}

\section{Dopaminergic modulation}

For many years, dopaminergic signaling has been the focal point of substance abuse research. Common features of addictive substances include increasing dopaminergic tone in the NAc; increasing synaptic plasticity on mesolimbic dopamine neurons in the VTA; and, animals will reliably perform intracranial self-stimulation (ICSS) of dopaminergic processes (Wise, 1998). It is important to note, however, that such dopamine transmission is not limited to the classical mesolimbic dopamine system. DiChiara and colleagues demonstrated that drugs of abuse can increase dopamine concentrations in the BNST (Carboni et al., 2000). Further, administration of addictive substances, but not non-addictive drugs activate extracellular regulated kinase (ERK) via dopaminergic signaling (Valjent et al., 2004) in the BNST. Additionally disruption of dopamine D1 receptor (D1R) signaling in the BNST can attenuate psychostimulant and ethanol reinforcement (Epping-Jordan et al., 1998; Eiler et al., 2003).

These studies are additionally interesting because, as stated above, it has been shown that the 
BNST makes excitatory projections to VTA dopamine neurons possibly demonstrating a feedforward loop for reinforcing drugs (Georges and Aston-Jones, 2002).

As a result of the importance of dopamine in reward, our group has begun investigations into regions with high dopaminergic innervation. Focusing on the BNST, NAc and the dorsal striatum Healey et al. (2008) examined expression levels of tyrosine hydroxylase (TH, the rate limiting enzyme in the production of dopamine) and the dopamine transporter (DAT) following either chronic or chronic intermittent exposure to ethanol vapor (Healey et al., 2008). In this study, 4-6 hours following chronic ethanol exposure there was a significant reduction in DAT, but conversely, 4-6 hours following chronic intermittent ethanol exposure there was a significant increase in DAT expression in the NAc. Interestingly, however, there was no change in DAT expression in the BNST, in either condition, in tissue samples taken from the same exposed mice. This may be of functional significance as the BNST receives dopaminergic innervation from the PAG as well as the VTA. Competing forms of modification in the VTA and the PAG may have resulted in a lack of effect in the BNST in general.

Very recently our group investigated the possibility that dopamine may act by modulating glutamatergic transmission in the BNST (Kash et al., 2008b). Dopamine was found to increase excitability in a subset of neurons; and, in an activity dependent fashion, dopamine increased the frequency of spontaneous EPSCs in the dIBNST via signaling at D1 and D2 receptors. Due to reported anatomical and functional interactions between dopamine and corticotrophin releasing factor (CRF) in other brain regions (Riegel and Williams, 2008; Wanat et al., 2008) as well as the presence of CRF containing neurons and terminals within the BNST (Champagne et al., 1998), Kash, Nobis and colleagues sought to determine if dopamine was acting though $\mathrm{CRF}$ to increase glutamatergic transmission. Consistent with a dopamine-CRF interaction blocking CRF1 receptors can prevent the effects of dopamine, and CRF or Urocortin application alone can cause an increase in the miniature EPSC frequency. One possibility, therefore, is that dopamine likely acts through the D1 and D2 receptors to excite CRF containing cells within the BNST, thus releasing CRF in the BNST. In fact, dopamine can increase firing in neurons in the BNST recorded in current clamp (Kash et al., 2008b). Another possibility is that dopamine is acting on CRF afferents stemming from the CeA to cause the release of CRF. Additionally, Kash, Nobis et al. (2008B) demonstrated that cocaine (in vivo and in vitro) and the specific dopamine transporter blocker GBR12909 could produce an NMDAR dependent enhancement of short term potentiation (STP) following tetanus. The increase in STP was prevented by both a pan-dopamine and a CRF-R1 antagonist and was absent in the D1R knockout mouse. In other brain regions, both CRF and dopamine have been demonstrated to modulate LTP (Thompson et al., 2005; Fu et al., 2007), and it has been demonstrated that CRF can modulate dopaminergic neurons in the VTA (Riegel and Williams, 2008; Wanat et al., 2008); however, these data demonstrate for the first time that dopamine can trigger a CRF dependent modulation of STP. The CRF dependent STP enhancement of excitatory transmission in the BNST by dopamine and CRF therefore may lead to increased excitatory tone in the dopaminergic neurons of the VTA via both glutamate release and CRF, now stemming from BNST afferents (Rodaros et al., 2007), enhancement of firing. This plasticity may perhaps serve as a mechanism by which cognitive and limbic centers can create a feed forward loop on midbrain dopamine neurons to enhance dopaminergic tone in several brain regions.

\section{Adrenergic Modulation}

Although dopaminergic signaling has been the focal point for substance abuse research for the past three decades, norepinephrine (NE) was originally thought to be a central player in mediating reward. In the 1970's it was shown that animals could perform ICSS of noradrenergic nuclei and pathways, interfering with NE signaling disrupted ICSS, and disruption of NE 
signaling was shown to inhibit opiate and ethanol self-administration. (For an in-depth review see Schroeder and Weinshenker 2007.) Recently NE, especially the projections from the ventral noradrenergic bundle (VNAB), has reemerged as a player in both reward and reinstatement to drug seeking. Olson and colleagues demonstrated that mice lacking the enzyme that produces NE (dopamine- $\beta$-hydroxylase or DBH) did not show a condition place preference to morphine, but this effect could be rescued by viral introduction of DBH to the nucleus of the tractus solitarius (NTS) (Olson et al., 2006). The BNST receives one of the densest projections of norepinephrine in the CNS stemming from the ventral noradrenergic bundle that is composed of the NTS and A1 cell groups (Ricardo and Koh, 1978; Woulfe et al., 1988; Forray and Gysling, 2004). Alteration of this projection, either by pharmacology (targeting individual ARs), or ablation, has demonstrated that this modulation can impact stress induced reinstatement to drug seeking, withdrawal aversion, fear behavior to predator stress and HPA axis regulation to a systemic stressor (yohimbine injection) (Delfs et al., 2000; Erb et al., 2000; Shaham et al., 2000; Wang et al., 2001; Fendt et al., 2005; Banihashemi and Rinaman, 2006). Furthermore blocking $\alpha_{1}$-ARs in the BNST reduces anxiety after a processive stressor (restraint) and decreases adrenocorticotrophic hormone (ACTH) suggesting that NE in the BNST can regulate HPA axis output to an anxiety inducing phenomena (Cecchi et al., 2002).

Our group, therefore, began a detailed investigation as to how norepinephrine modulates glutamatergic synapses in the BNST. Interestingly in different experiments in the dorsolateral BNST (dlBNST) norepinephrine could produce both an increase and decrease in glutamatergic efficacy in fEPSPs. Using pharmacology to dissect which receptors were responsible, Egli et al. showed that $\alpha_{2}$-AR stimulation resulted in a strong, but transient, suppression of glutamatergic signaling. $\beta$-AR stimulation, however, resulted in a transient increase in glutamatergic signaling (Egli et al., 2005). Intriguingly, stimulating $\beta$-AR could not account for the entire observed increase in transmission and the increase could be subsequently blocked by an $\alpha_{2}$-AR antagonist, suggesting a synergistic mechanism between $\beta$-ARs and $\alpha_{2}$-ARs. This data is further complicated by recent data examining the actions of $\alpha_{2}$-ARs (see below (Davis et al., 2008)). In the vlBNST however, norepinephrine only produced the transient decrease in fEPSPs which was shown to be mediated via the $\alpha_{2 \mathrm{~A}}$-AR.

The studies by Egli et al. suggested that norepinephrine modulated excitatory synapses in the BNST via the $\alpha_{2}$-and $\beta$-AR alone, excluding a role for the $\alpha_{1}$-AR. It has been shown, however, that $\alpha_{1}$-ARs can modulate glutamatergic transmission in other nuclei. They have, in fact, been demonstrated to act in a promiscuous manner: increasing glutamatergic tone in the hypothalamus (Gordon and Bains, 2003; Gordon et al., 2005; Gordon and Bains, 2005) and decreasing glutamatergic tone in the hippocampus and visual cortex (via a LTD mechanism) (Kirkwood et al., 1999; Scheiderer et al., 2004). mRNAs for the $\alpha_{1}$-AR subtypes are expressed in the BNST (Day et al., 1997), activation of $\alpha_{1}$-ARs can cause increases in GABAergic tone (Dumont and Williams, 2004) and early evidence suggested that $\alpha_{1}$-ARs could depress glutamatergic transmission (Sawada and Yamamoto, 1981). Utilizing the $\alpha_{1}$-AR agonist methoxamine we demonstrated that $\alpha_{1}$-AR activation can cause an LTD of glutamatergic transmission in the BNST (McElligott and Winder, 2008). A very intriguing aspect of this LTD was that it was dependent on the duration of exposure to NE. This observation may play a critical role of adrenergic modulation within the BNST as various groups have shown that using restraint as a psychological stressor can significantly increase noradrenergic tone in the BNST (via microdialysis) for several minutes following the termination of the stressor (Pacak et al., 1995; Cecchi et al., 2002). Therefore, it may be beneficial to the organism to only engage this type of plasticity only under extreme conditions of psychological stress when NE levels are most robust to perhaps disinhibit projections to nuclei like the PVN or inhibit projections to the VTA. 
We next characterized the induction of $\alpha_{1}$-AR LTD and were surprised to find that unlike the hippocampus and visual cortex, where it has also been described (Kirkwood et al., 1999; Scheiderer et al., 2004), $\alpha_{1}$-AR LTD in the BNST is expressed independently of NMDARs, but it is dependent on L-type voltage gated calcium channels. This suggests that $\alpha_{1}$-AR LTD is induced independently of presynaptic glutamatergic control coming from limbic and cortical inputs which could have physiological and psychological impact over animal behavior. For instance, this form of LTD could dissociate stress responses and drug craving from cognitive processes. This sort of disconnect is often alluded to by those with anxiety disorders and pathological substance abuse who are conscious of their pathological conditions yet are unable to overcome them. Although additional research would need to be performed to solidify this hypothesis, however we can envision a scenario where in these pathological conditions there is insufficient input from cognitive decision making domains to override more base feelings of anxiety or drug craving. Additionally, we found in two animal models, the $\alpha_{2 \mathrm{~A}}$ - AR and norepinephrine transporter knockout mice, with various affective disorder phenotypes ranging from depression/anxiety to altered reward profiles (Bohn et al., 2000; Xu et al., 2000; Schramm et al., 2001; Hall et al., 2002; Lahdesmaki et al., 2002; Dziedzicka-Wasylewska et al., 2006; Keller et al., 2006), that $\alpha_{1}$-AR LTD could not be induced under our conditions. It is likely that these two animal models lack the ability to induce $\alpha_{1}$-AR LTD due to receptor desensitization from chronically elevated levels of NE (Bohn et al., 2000; Xu et al., 2000; Lahdesmaki et al., 2002; Dziedzicka-Wasylewska et al., 2006).

Due to the robust reinstatement data involving noradrenergic signaling, our group's previous data examining $\alpha_{2}$-AR modulation of glutamatergic processes and the reported involvement of $\alpha_{2}$-ARs in the facilitation of extinction behaviors following fear conditioning (Cain et al., 2004 ), we probed the ability for $\alpha_{2}$-AR antagonism (with yohimbine) to facilitate extinction to the positive valence of cocaine. Surprisingly yohimbine impaired extinction to conditioned place preference to cocaine, and this impairment could not be mimicked with a more selective $\alpha_{2}$-AR antagonist (Davis et al., 2008). Furthermore, we showed that yohimbine robustly reduced glutamatergic transmission in the BNST independently of signaling via $\alpha_{2}$-ARs. While it is well known that yohimbine is not a selective drug, with off target effects mainly described at serotonin 5HT-1A receptors (Newman-Tancredi et al., 1998; Powell et al., 2005), it is often used for its anxiety inducing properties that are presumably evoked via enhanced adrenergic signaling via blockade of presynaptic ARs. We have demonstrated, however, that "off-target" effects of yohimbine have significant behavioral and physiological ramifications.

Recently, the BNST is gaining appreciation as a region involved in mediating the affective component of pain. Painful stimuli increase dialysis levels of NE in the BNST (Deyama et al., 2008a). Lesioning the BNST, blocking $\beta$-ARs and interfering with PKA signaling there reduces conditioned place aversion (CPA) to painful stimuli independently of nociception (Deyama et al., 2007; Deyama et al., 2008b). Interestingly, activating $\beta$-ARs and PKA in the BNST induced CPA independently of painful stimulation. Future studies in this area may aid in the development of non-narcotic analgesics for chronic pain.

\section{GABA and Neuropeptides}

Although the focus of this review is on glutamatergic transmission in the BNST, it is relevant to consider the importance of GABAergic ( $\gamma$-aminobutyric acid) transmission within this nucleus. The majority of neurons within the BNST are thought to be GABAergic and the BNST receives a robust $\mathrm{GABAergic}$ projection from the central nucleus of the amygdala $(\mathrm{CeA})$ which also can release CRF (Sakanaka et al., 1986). Another neuropeptide, neuropeptide Y (NPY) is expressed in adrenergic terminals and can be released upon high frequency stimulation of adrenergic neurons (Sawchenko et al., 1985; Pernow, 1988). In the vlBNST, NPY and CRF were found to respectively inhibit and increase GABAergic transmission within the BNST 
(Kash and Winder, 2006). NPY appeared to decrease transmission presynaptically via the Y2 receptor, while CRF increased inhibitory transmission postsynaptically via CRF-R1. The integration of CRF's effects on inhibitory transmission with the actions of CRF on glutamatergic transmission in the dlBNST (which projects to the vlBNST as well as other nuclei) will most likely shape the output to stress and reward nuclei.

NE has also been shown to modulate inhibitory transmission within the BNST. In neurons projecting to the VTA, NE can increase spontaneous inhibitory post synaptic current (sIPSC) frequency (Dumont and Williams, 2004). In conjunction with NE's inhibitory effect on glutatmatergic signaling, both acutely (Egli et al., 2005) and LTD (McElligott and Winder, 2008), this suggests that NE may globally reduce BNST output to several nuclei.

\section{Conclusions}

The BNST serves as an important relay between limbic inputs and stress and reward nuclei in the brain, where synaptic modification can dramatically alter the flow of information, and can be liable to the influence of stressors and drugs of abuse. Synaptic integration in this nucleus is undoubtedly a very complex phenomenon of which researchers have only begun to scratch the surface. Studies that have investigated the physiological properties and glutamatergic modulation within the BNST, however, have begun making progress towards reconciling animal behavior with the underlying molecular mechanism. Glutamatergic transmission is potently modified by stressors and drugs of abuse in this region. In particular, catecholamines may be released in the BNST under both stressful and rewarding conditions and they may engage alterations in glutamatergic transmission that could alter functional output behavioral responses to these experiences. The data suggesting that LTP can occur when a rewarding substance is self-administered, but not passively, administered strongly suggests that this plasticity may underlie learned associations with reward (Dumont et al., 2005) that have the potential to affect the entire reward circuitry. While at this time, the ramifications of this modulation as well as the other forms of plasticity in the BNST are unknown, future studies that strive to discover additional links between environmental influences and synaptic modulation will broaden our understanding of the importance of such modulation in behavioral output. For example, behavioral experiments involving paradigms of stress and reward in varying strains of mice can lead to candidate mRNAs and, ultimately proteins that may be involved in synaptic modulation manifesting as changes at the behavioral level. In such a way, using genetics, bioinformatics, behavioral studies, biochemistry and physiology to address the role of the BNST the field will hopefully contribute to the long term goals of eradicating substance abuse and anxiety disorders.

\section{References}

Allen Institute for Brain Science. Allen Brain Atlas. Allen Institute for Brain Science; 2008.

Arluison M, Vankova M, Cesselin F, Leviel V. Origin of some enkephalin-containing afferents to the ventro-medial region of the globus pallidus in the rat. Brain Res Bull 1990;25:25-34. [PubMed: 2207712]

Banihashemi L, Rinaman L. Noradrenergic inputs to the bed nucleus of the stria terminalis and paraventricular nucleus of the hypothalamus underlie hypothalamic-pituitary-adrenal axis but not hypophagic or conditioned avoidance responses to systemic yohimbine. J Neurosci 2006;26:1144211453. [PubMed: 17079674]

Bienkowski MS, Rinaman L. Noradrenergic inputs to the paraventricular hypothalamus contribute to hypothalamic-pituitary-adrenal axis and central Fos activation in rats after acute systemic endotoxin exposure. Neuroscience 2008;156:1093-1102. [PubMed: 18773942]

Bohn LM, Xu F, Gainetdinov RR, Caron MG. Potentiated opioid analgesia in norepinephrine transporter knock-out mice. J Neurosci 2000;20:9040-9045. [PubMed: 11124980] 
Boudaba C, Szabo K, Tasker JG. Physiological mapping of local inhibitory inputs to the hypothalamic paraventricular nucleus. J Neurosci 1996;16:7151-7160. [PubMed: 8929424]

Breese GR, Chu K, Dayas CV, Funk D, Knapp DJ, Koob GF, Le DA, O'Dell LE, Overstreet DH, Roberts AJ, Sinha R, Valdez GR, Weiss F. Stress enhancement of craving during sobriety: a risk for relapse. Alcohol Clin Exp Res 2005;29:185-195. [PubMed: 15714042]

Cain CK, Blouin AM, Barad M. Adrenergic transmission facilitates extinction of conditional fear in mice. Learn Mem 2004;11:179-187. [PubMed: 15054133]

Carboni E, Silvagni A, Rolando MT, Di Chiara G. Stimulation of in vivo dopamine transmission in the bed nucleus of stria terminalis by reinforcing drugs. J Neurosci 2000;20:RC102. [PubMed: 11027253]

Cecchi M, Khoshbouei H, Javors M, Morilak DA. Modulatory effects of norepinephrine in the lateral bed nucleus of the stria terminalis on behavioral and neuroendocrine responses to acute stress. Neuroscience 2002;112:13-21. [PubMed: 12044468]

Champagne D, Beaulieu J, Drolet G. CRFergic innervation of the paraventricular nucleus of the rat hypothalamus: a tract-tracing study. J Neuroendocrinol 1998;10:119-131. [PubMed: 9535058]

Chiamulera C, Epping-Jordan MP, Zocchi A, Marcon C, Cottiny C, Tacconi S, Corsi M, Orzi F, Conquet F. Reinforcing and locomotor stimulant effects of cocaine are absent in mGluR5 null mutant mice. Nat Neurosci 2001;4:873-874. [PubMed: 11528416]

Choi DC, Furay AR, Evanson NK, Ostrander MM, Ulrich-Lai YM, Herman JP. Bed nucleus of the stria terminalis subregions differentially regulate hypothalamic-pituitary-adrenal axis activity: implications for the integration of limbic inputs. J Neurosci 2007;27:2025-2034. [PubMed: 17314298]

Choi DC, Evanson NK, Furay AR, Ulrich-Lai YM, Ostrander MM, Herman JP. The anteroventral bed nucleus of the stria terminalis differentially regulates hypothalamic-pituitary-adrenocortical axis responses to acute and chronic stress. Endocrinology 2008a;149:818-826. [PubMed: 18039788]

Choi DC, Furay AR, Evanson NK, Ulrich-Lai YM, Nguyen MM, Ostrander MM, Herman JP. The role of the posterior medial bed nucleus of the stria terminalis in modulating hypothalamic-pituitaryadrenocortical axis responsiveness to acute and chronic stress. Psychoneuroendocrinology 2008b; 33:659-669. [PubMed: 18378095]

Crane JW, Buller KM, Day TA. Evidence that the bed nucleus of the stria terminalis contributes to the modulation of hypophysiotropic corticotropin-releasing factor cell responses to systemic interleukin-1beta. J Comp Neurol 2003;467:232-242. [PubMed: 14595770]

Crankshaw DL, Briggs JE, Olszewski PK, Shi Q, Grace MK, Billington CJ, Levine AS. Effects of intracerebroventricular ethanol on ingestive behavior and induction of c-Fos immunoreactivity in selected brain regions. Physiol Behav 2003;79:113-120. [PubMed: 12818716]

Cullinan WE, Herman JP, Watson SJ. Ventral subicular interaction with the hypothalamic paraventricular nucleus: evidence for a relay in the bed nucleus of the stria terminalis. J Comp Neurol 1993;332:120. [PubMed: 7685778]

Cullinan WE, Helmreich DL, Watson SJ. Fos expression in forebrain afferents to the hypothalamic paraventricular nucleus following swim stress. J Comp Neurol 1996;368:88-99. [PubMed: 8725295]

Cullinan WE, Ziegler DR, Herman JP. Functional role of local GABAergic influences on the HPA axis. Brain Struct Funct 2008;213:63-72. [PubMed: 18696110]

Davis AR, Shields AD, Brigman JL, Norcross M, McElligott ZA, Holmes A, Winder DG. Yohimbine impairs extinction of cocaine-conditioned place preference in an alpha2-adrenergic receptor independent process. Learn Mem 2008;15:667-676. [PubMed: 18772254]

Day HE, Campeau S, Watson SJ Jr, Akil H. Distribution of alpha 1a-, alpha 1b- and alpha 1d-adrenergic receptor mRNA in the rat brain and spinal cord. J Chem Neuroanat 1997;13:115-139. [PubMed: 9285356]

Delfs JM, Zhu Y, Druhan JP, Aston-Jones G. Noradrenaline in the ventral forebrain is critical for opiate withdrawal-induced aversion. Nature 2000;403:430-434. [PubMed: 10667795]

Deyama S, Nakagawa T, Kaneko S, Uehara T, Minami M. Involvement of the bed nucleus of the stria terminalis in the negative affective component of visceral and somatic pain in rats. Behav Brain Res 2007;176:367-371. [PubMed: 17101179] 
Deyama S, Katayama T, Kondoh N, Nakagawa T, Kaneko S, Yamaguchi T, Yoshioka M, Minami M. Role of enhanced noradrenergic transmission within the ventral bed nucleus of the stria terminalis in visceral pain-induced aversion in rats. Behav Brain Res. 2008a

Deyama S, Katayama T, Ohno A, Nakagawa T, Kaneko S, Yamaguchi T, Yoshioka M, Minami M. Activation of the beta-adrenoceptor-protein kinase A signaling pathway within the ventral bed nucleus of the stria terminalis mediates the negative affective component of pain in rats. J Neurosci 2008b;28:7728-7736. [PubMed: 18667605]

Dong H, Petrovich GD, Swanson LW. Organization of projections from the juxtacapsular nucleus of the BST: a PHAL study in the rat. Brain Res 2000;859:1-14. [PubMed: 10720609]

Dong HW, Swanson LW. Organization of axonal projections from the anterolateral area of the bed nuclei of the stria terminalis. J Comp Neurol 2004;468:277-298. [PubMed: 14648685]

Dong HW, Petrovich GD, Swanson LW. Topography of projections from amygdala to bed nuclei of the stria terminalis. Brain Res Brain Res Rev 2001a;38:192-246. [PubMed: 11750933]

Dong HW, Petrovich GD, Watts AG, Swanson LW. Basic organization of projections from the oval and fusiform nuclei of the bed nuclei of the stria terminalis in adult rat brain. J Comp Neurol 2001b; 436:430-455. [PubMed: 11447588]

Dong Y, Saal D, Thomas M, Faust R, Bonci A, Robinson T, Malenka RC. Cocaine-induced potentiation of synaptic strength in dopamine neurons: behavioral correlates in GluRA(-/-) mice. Proc Natl Acad Sci U S A 2004;101:14282-14287. [PubMed: 15375209]

Dumont EC, Williams JT. Noradrenaline triggers GABAA inhibition of bed nucleus of the stria terminalis neurons projecting to the ventral tegmental area. J Neurosci 2004;24:8198-8204. [PubMed: 15385602]

Dumont EC, Mark GP, Mader S, Williams JT. Self-administration enhances excitatory synaptic transmission in the bed nucleus of the stria terminalis. Nat Neurosci 2005;8:413-414. [PubMed: 15735642]

Dumont EC, Rycroft BK, Maiz J, Williams JT. Morphine produces circuit-specific neuroplasticity in the bed nucleus of the stria terminalis. Neuroscience 2008;153:232-239. [PubMed: 18343592]

Dunn JD. Plasma corticosterone responses to electrical stimulation of the bed nucleus of the stria terminalis. Brain Res 1987;407:327-331. [PubMed: 3567648]

Dziedzicka-Wasylewska M, Faron-Gorecka A, Kusmider M, Drozdowska E, Rogoz Z, Siwanowicz J, Caron MG, Bonisch H. Effect of antidepressant drugs in mice lacking the norepinephrine transporter. Neuropsychopharmacology 2006;31:2424-2432. [PubMed: 16554743]

Egli RE, Winder DG. Dorsal and ventral distribution of excitable and synaptic properties of neurons of the bed nucleus of the stria terminalis. J Neurophysiol 2003;90:405-414. [PubMed: 12649311]

Egli RE, Kash TL, Choo K, Savchenko V, Matthews RT, Blakely RD, Winder DG. Norepinephrine modulates glutamatergic transmission in the bed nucleus of the stria terminalis. Neuropsychopharmacology 2005;30:657-668. [PubMed: 15602500]

Eiler WJ 2nd, Seyoum R, Foster KL, Mailey C, June HL. D1 dopamine receptor regulates alcoholmotivated behaviors in the bed nucleus of the stria terminalis in alcohol-preferring $(\mathrm{P})$ rats. Synapse 2003;48:45-56. [PubMed: 12557272]

Epping-Jordan MP, Markou A, Koob GF. The dopamine D-1 receptor antagonist SCH 23390 injected into the dorsolateral bed nucleus of the stria terminalis decreased cocaine reinforcement in the rat. Brain Res 1998;784:105-115. [PubMed: 9518570]

Erb S, Hitchcott PK, Rajabi H, Mueller D, Shaham Y, Stewart J. Alpha-2 adrenergic receptor agonists block stress-induced reinstatement of cocaine seeking. Neuropsychopharmacology 2000;23:138150. [PubMed: 10882840]

Fendt M, Siegl S, Steiniger-Brach B. Noradrenaline transmission within the ventral bed nucleus of the stria terminalis is critical for fear behavior induced by trimethylthiazoline, a component of fox odor. J Neurosci 2005;25:5998-6004. [PubMed: 15976089]

Forray MI, Gysling K. Role of noradrenergic projections to the bed nucleus of the stria terminalis in the regulation of the hypothalamic-pituitary-adrenal axis. Brain Res Brain Res Rev 2004;47:145-160. [PubMed: 15572169]

Fu Y, Pollandt S, Liu J, Krishnan B, Genzer K, Orozco-Cabal L, Gallagher JP, Shinnick-Gallagher P. Long-term potentiation (LTP) in the central amygdala (CeA) is enhanced after prolonged withdrawal 
from chronic cocaine and requires CRF1 receptors. J Neurophysiol 2007;97:937-941. [PubMed: 17079348]

George DT, Nutt DJ, Dwyer BA, Linnoila M. Alcoholism and panic disorder: is the comorbidity more than coincidence? Acta Psychiatr Scand 1990;81:97-107. [PubMed: 2183544]

Georges F, Aston-Jones G. Activation of ventral tegmental area cells by the bed nucleus of the stria terminalis: a novel excitatory amino acid input to midbrain dopamine neurons. J Neurosci 2002;22:5173-5187. [PubMed: 12077212]

Gordon GR, Bains JS. Priming of excitatory synapses by alpha1 adrenoceptor-mediated inhibition of group III metabotropic glutamate receptors. J Neurosci 2003;23:6223-6231. [PubMed: 12867506]

Gordon GR, Bains JS. Noradrenaline triggers multivesicular release at glutamatergic synapses in the hypothalamus. J Neurosci 2005;25:11385-11395. [PubMed: 16339033]

Gordon GR, Baimoukhametova DV, Hewitt SA, Rajapaksha WR, Fisher TE, Bains JS. Norepinephrine triggers release of glial ATP to increase postsynaptic efficacy. Nat Neurosci 2005;8:1078-1086. [PubMed: 15995701]

Grueter BA, Winder DG. Group II and III metabotropic glutamate receptors suppress excitatory synaptic transmission in the dorsolateral bed nucleus of the stria terminalis. Neuropsychopharmacology 2005;30:1302-1311. [PubMed: 15812571]

Grueter BA, McElligott ZA, Winder DG. Group I mGluRs and long-term depression: potential roles in addiction? Mol Neurobiol 2007;36:232-244. [PubMed: 17955198]

Grueter BA, McElligott ZA, Robison AJ, Mathews GC, Winder DG. In vivo metabotropic glutamate receptor 5 (mGluR5) antagonism prevents cocaine-induced disruption of postsynaptically maintained mGluR5-dependent long-term depression. J Neurosci 2008;28:9261-9270. [PubMed: 18784306]

Grueter BA, Gosnell HB, Olsen CM, Schramm-Sapyta NL, Nekrasova T, Landreth GE, Winder DG. Extracellular-signal regulated kinase 1-dependent metabotropic glutamate receptor 5-induced longterm depression in the bed nucleus of the stria terminalis is disrupted by cocaine administration. $\mathrm{J}$ Neurosci 2006;26:3210-3219. [PubMed: 16554472]

Hall FS, Li XF, Sora I, Xu F, Caron M, Lesch KP, Murphy DL, Uhl GR. Cocaine mechanisms: enhanced cocaine, fluoxetine and nisoxetine place preferences following monoamine transporter deletions. Neuroscience 2002;115:153-161. [PubMed: 12401330]

Hammack SE, Mania I, Rainnie DG. Differential expression of intrinsic membrane currents in defined cell types of the anterolateral bed nucleus of the stria terminalis. J Neurophysiol 2007;98:638-656. [PubMed: 17537902]

Hasue RH, Shammah-Lagnado SJ. Origin of the dopaminergic innervation of the central extended amygdala and accumbens shell: a combined retrograde tracing and immunohistochemical study in the rat. J Comp Neurol 2002;454:15-33. [PubMed: 12410615]

Healey JC, Winder DG, Kash TL. Chronic ethanol exposure leads to divergent control of dopaminergic synapses in distinct target regions. Alcohol 2008;42:179-190. [PubMed: 18358675]

Herrero MJ, Domingo-Salvany A, Torrens M, Brugal MT. Psychiatric comorbidity in young cocaine users: induced versus independent disorders. Addiction 2008;103:284-293. [PubMed: 18199307]

Herring BE, Mayfield RD, Camp MC, Alcantara AA. Ethanol-induced Fos immunoreactivity in the extended amygdala and hypothalamus of the rat brain: focus on cholinergic interneurons of the nucleus accumbens. Alcohol Clin Exp Res 2004;28:588-597. [PubMed: 15100610]

Herzig V, Schmidt WJ. Effects of MPEP on locomotion, sensitization and conditioned reward induced by cocaine or morphine. Neuropharmacology 2004;47:973-984. [PubMed: 15555632]

Herzig V, Capuani EM, Kovar KA, Schmidt WJ. Effects of MPEP on expression of food-, MDMA- or amphetamine-conditioned place preference in rats. Addict Biol 2005;10:243-249. [PubMed: 16109585]

Kash TL, Winder DG. Neuropeptide Y and corticotropin-releasing factor bi-directionally modulate inhibitory synaptic transmission in the bed nucleus of the stria terminalis. Neuropharmacology 2006;51:1013-1022. [PubMed: 16904135]

Kash TL, Matthews RT, Winder DG. Alcohol inhibits NR2B-containing NMDA receptors in the ventral bed nucleus of the stria terminalis. Neuropsychopharmacology 2008a;33:1379-1390. [PubMed: 17625498] 
Kash TL, Nobis WP, Matthews RT, Winder DG. Dopamine enhances fast excitatory synaptic transmission in the extended amygdala by a CRF-R1-dependent process. J Neurosci 2008b; 28:13856-13865. [PubMed: 19091975]

Kauer JA, Malenka RC. Synaptic plasticity and addiction. Nat Rev Neurosci 2007;8:844-858. [PubMed: 17948030]

Keller NR, Diedrich A, Appalsamy M, Miller LC, Caron MG, McDonald MP, Shelton RC, Blakely RD, Robertson D. Norepinephrine transporter-deficient mice respond to anxiety producing and fearful environments with bradycardia and hypotension. Neuroscience 2006;139:931-946. [PubMed: 16515844]

Kirkwood A, Rozas C, Kirkwood J, Perez F, Bear MF. Modulation of long-term synaptic depression in visual cortex by acetylcholine and norepinephrine. J Neurosci 1999;19:1599-1609. [PubMed: 10024347]

Knapp DJ, Braun CJ, Duncan GE, Qian Y, Fernandes A, Crews FT, Breese GR. Regional specificity of ethanol and NMDA action in brain revealed with FOS-like immunohistochemistry and differential routes of drug administration. Alcohol Clin Exp Res 2001;25:1662-1672. [PubMed: 11707641]

Kushner MG, Abrams K, Borchardt C. The relationship between anxiety disorders and alcohol use disorders: a review of major perspectives and findings. Clin Psychol Rev 2000;20:149-171. [PubMed: 10721495]

Lahdesmaki J, Sallinen J, MacDonald E, Kobilka BK, Fagerholm V, Scheinin M. Behavioral and neurochemical characterization of alpha(2A)-adrenergic receptor knockout mice. Neuroscience 2002;113:289-299. [PubMed: 12127086]

Larriva-Sahd J. Histological and cytological study of the bed nuclei of the stria terminalis in adult rat. II. Oval nucleus: extrinsic inputs, cell types, neuropil, and neuronal modules. J Comp Neurol 2006;497:772-807. [PubMed: 16786552]

Lee Y, Davis M. Role of the hippocampus, the bed nucleus of the stria terminalis, and the amygdala in the excitatory effect of corticotropin-releasing hormone on the acoustic startle reflex. J Neurosci 1997;17:6434-6446. [PubMed: 9236251]

Liu L, Wong TP, Pozza MF, Lingenhoehl K, Wang Y, Sheng M, Auberson YP, Wang YT. Role of NMDA receptor subtypes in governing the direction of hippocampal synaptic plasticity. Science 2004;304:1021-1024. [PubMed: 15143284]

Malenka RC, Bear MF. LTP and LTD: an embarrassment of riches. Neuron 2004;44:5-21. [PubMed: 15450156]

Mallon AP, Auberson YP, Stone TW. Selective subunit antagonists suggest an inhibitory relationship between NR2B and NR2A-subunit containing N-methyl-D: -aspartate receptors in hippocampal slices. Exp Brain Res 2005;162:374-383. [PubMed: 15580338]

Malsbury CW, McKay K. A sex difference in the pattern of substance P-like immunoreactivity in the bed nucleus of the stria terminalis. Brain Res 1987;420:365-370. [PubMed: 2445435]

Massey PV, Johnson BE, Moult PR, Auberson YP, Brown MW, Molnar E, Collingridge GL, Bashir ZI. Differential roles of NR2A and NR2B-containing NMDA receptors in cortical long-term potentiation and long-term depression. J Neurosci 2004;24:7821-7828. [PubMed: 15356193]

Massi L, Elezgarai I, Puente N, Reguero L, Grandes P, Manzoni OJ, Georges F. Cannabinoid receptors in the bed nucleus of the stria terminalis control cortical excitation of midbrain dopamine cells in vivo. J Neurosci 2008;28:10496-10508. [PubMed: 18923026]

McDonald AJ. Neurons of the bed nucleus of the stria terminalis: a golgi study in the rat. Brain Res Bull 1983;10:111-120. [PubMed: 6824959]

McDonald AJ. Cortical pathways to the mammalian amygdala. Prog Neurobiol 1998;55:257-332. [PubMed: 9643556]

McElligott ZA, Winder DG. Alpha1-adrenergic receptor-induced heterosynaptic long-term depression in the bed nucleus of the stria terminalis is disrupted in mouse models of affective disorders. Neuropsychopharmacology 2008;33:2313-2323. [PubMed: 18046308]

McGeehan AJ, Olive MF. The mGluR5 antagonist MPEP reduces the conditioned rewarding effects of cocaine but not other drugs of abuse. Synapse 2003;47:240-242. [PubMed: 12494407] 
Meloni EG, Jackson A, Gerety LP, Cohen BM, Carlezon WA Jr. Role of the bed nucleus of the stria terminalis (BST) in the expression of conditioned fear. Ann N Y Acad Sci 2006;1071:538-541. [PubMed: 16891614]

Newman-Tancredi A, Nicolas JP, Audinot V, Gavaudan S, Verriele L, Touzard M, Chaput C, Richard N, Millan MJ. Actions of alpha2 adrenoceptor ligands at alpha2A and 5-HT1A receptors: the antagonist, atipamezole, and the agonist, dexmedetomidine, are highly selective for alpha2A adrenoceptors. Naunyn Schmiedebergs Arch Pharmacol 1998;358:197-206. [PubMed: 9750005]

Olson VG, Heusner CL, Bland RJ, During MJ, Weinshenker D, Palmiter RD. Role of noradrenergic signaling by the nucleus tractus solitarius in mediating opiate reward. Science 2006;311:1017-1020. [PubMed: 16484499]

Pacak K, McCarty R, Palkovits M, Kopin IJ, Goldstein DS. Effects of immobilization on in vivo release of norepinephrine in the bed nucleus of the stria terminalis in conscious rats. Brain Res 1995;688:242246. [PubMed: 8542318]

Pernow J. Co-release and functional interactions of neuropeptide $\mathrm{Y}$ and noradrenaline in peripheral sympathetic vascular control. Acta Physiol Scand Suppl 1988;568:1-56. [PubMed: 3232527]

Powell SB, Palomo J, Carasso BS, Bakshi VP, Geyer MA. Yohimbine disrupts prepulse inhibition in rats via action at 5-HT1A receptors, not alpha2-adrenoceptors. Psychopharmacology (Berl) 2005;180:491-500. [PubMed: 15719216]

Rainnie DG. Neurons of the bed nucleus of the stria terminalis (BNST). Electrophysiological properties and their response to serotonin. Ann N Y Acad Sci 1999;877:695-699. [PubMed: 10415686]

Ricardo JA, Koh ET. Anatomical evidence of direct projections from the nucleus of the solitary tract to the hypothalamus, amygdala, and other forebrain structures in the rat. Brain Res 1978;153:1-26. [PubMed: 679038]

Riegel AC, Williams JT. CRF facilitates calcium release from intracellular stores in midbrain dopamine neurons. Neuron 2008;57:559-570. [PubMed: 18304485]

Rodaros D, Caruana DA, Amir S, Stewart J. Corticotropin-releasing factor projections from limbic forebrain and paraventricular nucleus of the hypothalamus to the region of the ventral tegmental area. Neuroscience 2007;150:8-13. [PubMed: 17961928]

Saal D, Dong Y, Bonci A, Malenka RC. Drugs of abuse and stress trigger a common synaptic adaptation in dopamine neurons. Neuron 2003;37:577-582. [PubMed: 12597856]

Sakanaka M, Shibasaki T, Lederis K. Distribution and efferent projections of corticotropin-releasing factor-like immunoreactivity in the rat amygdaloid complex. Brain Res 1986;382:213-238. [PubMed: 2428439]

Sareen J, Chartier M, Paulus MP, Stein MB. Illicit drug use and anxiety disorders: findings from two community surveys. Psychiatry Res 2006;142:11-17. [PubMed: 16712953]

Sawada S, Yamamoto C. Postsynaptic inhibitory actions of catecholamines and opioid peptides in the bed nucleus of the stria terminalis. Exp Brain Res 1981;41:264-270. [PubMed: 6260525]

Sawchenko PE, Swanson LW, Grzanna R, Howe PR, Bloom SR, Polak JM. Colocalization of neuropeptide $\mathrm{Y}$ immunoreactivity in brainstem catecholaminergic neurons that project to the paraventricular nucleus of the hypothalamus. J Comp Neurol 1985;241:138-153. [PubMed: 3840810]

Scheiderer CL, Dobrunz LE, McMahon LL. Novel form of long-term synaptic depression in rat hippocampus induced by activation of alpha 1 adrenergic receptors. J Neurophysiol 2004;91:10711077. [PubMed: 14573563]

Schramm NL, McDonald MP, Limbird LE. The alpha(2a)-adrenergic receptor plays a protective role in mouse behavioral models of depression and anxiety. J Neurosci 2001;21:4875-4882. [PubMed: 11425914]

Schulz D, Canbeyli RS. Lesion of the bed nucleus of the stria terminalis enhances learned despair. Brain Res Bull 2000;52:83-87. [PubMed: 10808077]

Shaham Y, Erb S, Stewart J. Stress-induced relapse to heroin and cocaine seeking in rats: a review. Brain Res Brain Res Rev 2000;33:13-33. [PubMed: 10967352]

Sullivan GM, Apergis J, Bush DE, Johnson LR, Hou M, Ledoux JE. Lesions in the bed nucleus of the stria terminalis disrupt corticosterone and freezing responses elicited by a contextual but not by a specific cue-conditioned fear stimulus. Neuroscience 2004;128:7-14. [PubMed: 15450349] 
Thompson AM, Swant J, Wagner JJ. Cocaine-induced modulation of long-term potentiation in the CA1 region of rat hippocampus. Neuropharmacology 2005;49:185-194. [PubMed: 15996567]

Ungless MA, Whistler JL, Malenka RC, Bonci A. Single cocaine exposure in vivo induces long-term potentiation in dopamine neurons. Nature 2001;411:583-587. [PubMed: 11385572]

Valjent E, Pages C, Herve D, Girault JA, Caboche J. Addictive and non-addictive drugs induce distinct and specific patterns of ERK activation in mouse brain. Eur J Neurosci 2004;19:1826-1836. [PubMed: 15078556]

Vik PW. Methamphetamine use by incarcerated women: comorbid mood and anxiety problems. Womens Health Issues 2007;17:256-263. [PubMed: 17544297]

Waddell J, Morris RW, Bouton ME. Effects of bed nucleus of the stria terminalis lesions on conditioned anxiety: aversive conditioning with long-duration conditional stimuli and reinstatement of extinguished fear. Behav Neurosci 2006;120:324-336. [PubMed: 16719697]

Walker DL, Davis M. Double dissociation between the involvement of the bed nucleus of the stria terminalis and the central nucleus of the amygdala in startle increases produced by conditioned versus unconditioned fear. J Neurosci 1997;17:9375-9383. [PubMed: 9364083]

Walker JR, Ahmed SH, Gracy KN, Koob GF. Microinjections of an opiate receptor antagonist into the bed nucleus of the stria terminalis suppress heroin self-administration in dependent rats. Brain Res 2000;854:85-92. [PubMed: 10784110]

Walter A, Mai JK, Lanta L, Gorcs T. Differential distribution of immunohistochemical markers in the bed nucleus of the stria terminalis in the human brain. J Chem Neuroanat 1991;4:281-298. [PubMed: 1718318]

Wanat MJ, Hopf FW, Stuber GD, Phillips PE, Bonci A. Corticotropin-releasing factor increases mouse ventral tegmental area dopamine neuron firing through a protein kinase C-dependent enhancement of Ih. J Physiol 2008;586:2157-2170. [PubMed: 18308824]

Wang X, Cen X, Lu L. Noradrenaline in the bed nucleus of the stria terminalis is critical for stress-induced reactivation of morphine-conditioned place preference in rats. Eur J Pharmacol 2001;432:153-161. [PubMed: 11740951]

Weitlauf C, Egli RE, Grueter BA, Winder DG. High-frequency stimulation induces ethanol-sensitive long-term potentiation at glutamatergic synapses in the dorsolateral bed nucleus of the stria terminalis. J Neurosci 2004;24:5741-5747. [PubMed: 15215296]

Weitlauf C, Honse Y, Auberson YP, Mishina M, Lovinger DM, Winder DG. Activation of NR2Acontaining NMDA receptors is not obligatory for NMDA receptor-dependent long-term potentiation. J Neurosci 2005;25:8386-8390. [PubMed: 16162920]

Whitlock JR, Heynen AJ, Shuler MG, Bear MF. Learning induces long-term potentiation in the hippocampus. Science 2006;313:1093-1097. [PubMed: 16931756]

Wise RA. Drug-activation of brain reward pathways. Drug Alcohol Depend 1998;51:13-22. [PubMed: 9716927]

Wolf ME. The role of excitatory amino acids in behavioral sensitization to psychomotor stimulants. Prog Neurobiol 1998;54:679-720. [PubMed: 9560846]

Woulfe JM, Hrycyshyn AW, Flumerfelt BA. Collateral axonal projections from the A1 noradrenergic cell group to the paraventricular nucleus and bed nucleus of the stria terminalis in the rat. Exp Neurol 1988;102:121-124. [PubMed: 2846338]

Xu F, Gainetdinov RR, Wetsel WC, Jones SR, Bohn LM, Miller GW, Wang YM, Caron MG. Mice lacking the norepinephrine transporter are supersensitive to psychostimulants. Nat Neurosci 2000;3:465-471. [PubMed: 10769386] 